\title{
PENDIDIKAN KETERAMPILAN BERPIKIR KRITIS DAN KREATIF SERTA KEPEKAAN SOSIAL GURU DALAM MENGAJAR
}

Oleh :

\author{
I Nyoman Sueca \\ Dosen Institut Hindu Dharma Negeri Denpasar \\ inyomansueca64@gmail.com
}

\begin{abstract}
Education Skills is expected to provide knowledge that allows people to overcome life problems in their professional duties and in daily life. Therefore teachers in carrying out their duties professionally, critical and creative thinking skills are needed, problem solving skills and decision making, as well as in Higher Education lecturers educate their students to be able to think critically and creatively in solving all problems they face. The development of critical and creative thinking skills carried out by teachers and lecturers is an educational orientation that fits in life situations that change very quickly.
\end{abstract}

\section{Keywords : education skills}

\section{PENDAHULUAN}

Pendidikan diharapkan memberikan pengetahuan yang memungkinkan orang dapat mengatasi masalah-masalah kehidupan dalam tugas-tugas profesionalnya dan dalam kehidupan sehari-hari. Namun, dalam kondisi kehidupan yang berubah dengan sangat cepat seperti sekarang ini, kerap kali pengetahuan yang kita miliki tidak dapat kita terapkan untuk mengatasi masalah-masalah yang muncul. Oleh karena itu guru dalam menjalankan tupoksinya secara profesional, diperlukan keterampilan berpikir kritis dan kreatif, keterampilan memecahkan masalah dan mengambil keputusan, demikian juga di Perguruan Tinggi dosen mendidik mahasiswanya untuk dapat berpikir kritis dan kreatif dalam memcahakan segala permasalahan yang dihadapi. Untuk itu, perlu adanya kepekaan terhadap masalah yang muncul dalam masyarakat dan kejelian untuk mengidentifikasi masalah serta merumuskannya secara tepat.

Guru dan dosen pada saat mengajar untuk memecahkan masalah memerlukan penggunaan keterampilan berpikir secara terpadu dan dasar pengetahuan yang relevan. Keterampilan berpikir dan pengetahuan yang relevan yang dimiliki dapat diumpamakan sebagai keterampilan memasak dan bahanbahan yang dimasak. Seseorang tidak dapat rnenyiapkan masakan tanpa bahan masakan beserta bumbu-burnbunya, demikian juga ia tidak dapat berbuat banyak terhadap bahanbahan masakan tersebut tanpa memiliki keterampilan memasak. Seperti halnya ahli masak yang dapat rnenghasilkan masakan lezat dari bahan masakan seadanya, orang yang mahir berpikir kritis dan kreatif dapat menghasilkan solusi masalah secara tepat dari informasi yang terbatas. Sebaliknya, seseorang yang tidak terampil berpikir kritis dan kreatif tidak menghasilkan pemecahan masalah yang tepat, meskipun tersedia cukup banyak informasi yang relevan.

Dapat dipahami bahwa suatu masalah tidak dapat diatasi tanpa dasar pengetahuan yang relevan. Masalah pendidikan tidak dapat diatasi tanpa pengetahuan dalam bidang pendidikan, masalah hukum tidak dapat diatasi tanpa dasar pengetahuan hukum, dan sebagainya. Pengetahuan untuk mengatasi 
masalah bersifat spesifik, sebaliknya keterampilan berpikir dapat diterapkan pada berbagai bidang atau lintas disiplin ilmu. OIeh karena itu, pengembangan keterampilan berpikir kritis dan kreatif yang dilakukan guru merupakan orientasi pendidikan yang cocok dalam situasi kehidupan yang mengalarni perubahan yang sangat cepat.

Kemampuan guru mengatasi masalah selain bergantung pada keterampilan berpikir kritis dan kreatif juga pada persepsi seseorang. Guru yang mengajar tidak mungkin dapat mengatasi masalah apabila tidak menyadari adanya masalah-masalah yang muncul dalam kehidupan atau tidak memiliki kepekaan sosial. Guru juga tidak dapat mengatasi masalah apabila takut tidak berhasil. Guru tidak pula berusaha mengatasi masalah apabila merasa tidak berdaya untuk melaksanakannya. Persepsi seseorang dalam mengatasi masalah erat kaitannya dengan sikapnya terhadap kemampuan diri dalam mengatasi masalah.

\section{PEMBAHASAN}

\section{Keterampilan Berpikir Kritis}

Guru dalam mengajar pengembangan keterampilan berpikir kritis merupakan suatu keharusan untuk mampu mengahdapi dan mengatasi permasalahan dalam kelas, tidak terkecuali perguruan tinggi yang mendidik calon guru. Perguruan tinggi keguruan bahkan perlu didesain untuk menolong mahasiswa mengembangkan keterampilan berpikir kritis, baik untuk dirinya sendiri maupun untuk anak didiknya kelak.

Senada dengan ide di atas, Stice menyatakan "The what is important, but we sbouidpay attention to the bows andthe whys" Stice (dalam Darmiyati Zuchdi, 2009:124). Untuk dapat menjawab pertanyaan apa, bagaimana, dan mengapa mengenai setiap hal yang dipelajari, diperlukan latihan. Mulamula perlu latihan mengemukakan konsepkonsep tersebut dengan berpikir secara mendalam, sehingga dapat menguasainya dengan baik. Dengan kata lain, perlu latihan berpikir analitis, "bagaimana sesuatu terjadi dan mengapa hal itu terjadi". Dengan membiasakan diri berpikir analitis, mahasiswa akan memiliki ide-ide cemerlang, mau bekerja keras, ambisius (dalam arti bergairah untuk maju), sekaligus dapat mengingat dengan baik.

Untuk mengembangkan kemampuan berpikir kritis bagi para siswa, di Sekolah demikian juga para Mahasiswa di Perguruan Tinggi ditawarkan mata kuliah Pattern of Problem Solving untuk pertama kalinya. Tugas-tugas yang diberikan oleh guru kepada siswanya berupa kegiatan membaca bahanbahan bacaan mengenai berpikir kritis dan pemecahan masalah, Pada akhir proses belajar mengajar, siswa ditugasi untuk menjawab beberapa soal kalau waktunya tidak cukup soal-soal yang diberikan gurunya bisa dikerjakan di rumah yang tujuannya agar siswa dapat berpikir kritis dan kreatif sebagai pembiasaan dirinya.

Dalam kurikulum di tingkat sekolahsekolah telah termuat mata pelajaran matematika, kalau ditingkat sekolah menengah disamping pelajaran matematika, fisika dan juga ilmu pasti yang lain yang memiliki ciri spesipik yang sangat sesuai untuk mengembangkan keterampilan berpikir kritis siswa. Sebagai salah satu latihan untuk mencapai kualitas siswa yang memiliki tanggung jawab sosial dan moral. Agar dapat membangun suatu budaya kritis maka pembiasaan berpikir kritis perlu dilakukan dalam setiap pembelajaran, meskipun dengan kadar yang berbeda-beda sesuai dengan sifat siswa yang bersangkutan. Hal ini hanya mungkin dapat dicapai apabila guru dan siswa melakukan kegiatan berpikir kritis sebagai suatu kebutuhan, berdasarkan kesadaran akan manfaatnya. Untuk itu, hendaknya dipilih topik-topik yang kontekstual dan fungsional, yang terkait dengan masalah-masalah yang memang benar-benar dihadapi dalam kehidupan. Siswa untuk dapat berpikir kritis guru setealah mengajar mesti memberikan topik-topik yang berkenaan dengan problem kehidupan yang relevan untuk dijadikan fokus diskusi untuk mengasah pola pikir. Pendidikan juga dapat membekali masyarakat unutk dapat berpikir dan dibekali ingin tahu, 
rasa ingin tahu inilah yang mendorong untuk mengenal, memahami dan menjelaskan gejala-gejala alam, serta berusaha untuk memecahkan masalah yang dihadapi. Dari dorongan rasa ingin tahu dan berusaha untuk memahami dan memecahkan masalah menyebabkan manusia dapat mengumpulkan pengetahuan.

Pengetahuan yang diperoleh mula-mula terbatas pada hasil pengamatan terhadap gejala alam yang ada, kemudian semakin bertambah dengan pengetahuan yang diperoleh dari hasil pemikirannya. Kemudian pengetahuan yang didapatnya, terus dikembnagkan sehingga manusia sampai saat ini terus berkembang dan akhirnya manusia dapat menciptakan beberapa benda untuk memenuhi kebutuhan sehari-hari

\section{Keterampilan Berpikir Kreatif}

Keterampilan berpikir kreatif, yaitu keterampilan siswa dalam menggunakan proses berpikirnya untuk menghasilkan suatu ide yang baru, konstruktif, dan baik, berdasarkan konsep-konsep yang rasional, persepsi, dan intuisi individu (Suprapto, 1997: 7). Berpikir kreatif melibatkan rasio dan intuisi. Dalam hal ini, Rubinstein dan Firstenberg (dalam Zuchdi, 2009:127) berpendapat bahwa dengan saran berpikir rasional dan imajinatif, guru dapat mengembangkan kapasitas untuk mengenal pola-pola baru dan prinsip-prinsip baru, menyatukan fenomena yang berbeda-beda, dan menyederhanakan situasi yang kompleks. Inilah hakikat berpikir kreatif dan produktif, yang memungkinkan seseorang dapat memecahkan masalah.

Guna menjaga eksistensi guru sebagai pendidik dalam menghadapi perubahan dunia yang sangat cepat dan kompleks harus mau menerima informasi baru, guru harus menyimpan dan memprosesnya, dan guru harus terus memantau perubahan yang terjadi. Jika hanya menerima informasi yang sesuai dengan model-model (misalnya model pembelajaran) yang telah guru miliki, maka proses belajar berhenti. Proses belajar terjadi jika guru mau menerima informasi yang tidak sesuai dengan model-model yang mereka miliki. Proses belajar terjadi jika pertentangan yang ditimbulkan oleh informasi yang tidak cocok dengan model yang guru miliki menyebabkan guru mengubahnya. Berpikir imajinatif dan keberarnan melakukan kesalahan dapat menggantikan kepuasan diri, sehingga guru dapat mengantisipasi perubahan, tidak hanya mereaksi perubahan tanpa kesiapan. Tindakan demikian yang biasa disebut dengan istilah proaktif, siap menyongsong perubahan.

Orang-orang yang kreatif bersikap positif terhadap pemecahan masalah. Mereka menganggap masalah sebagai suatu tantangan, suatu kesempatan untuk memperoleh pengalaman baru, dan suatu pengayaan perbendaharaan sarana berpikir, suatu pengalaman belajar. Dengan sikap positif, usaha yang mungkin menyebabkan frustrasi dalam mencari suatu solusi terkompensasi (terimbangi) oleh pengalamanpengalaman yang dapat diperoleh dalam proses menemukan suatu solusi. Orang-orang yang kreatif memandang suatu rintangan dalam memecahkan masalah sebagai suatu tantangan, suatu petualangan intelektual dan emosional. Orang-orang yang kreatif tidak lari dari situasi yang kompleks. Mereka menyenangi pengalaman-pengalaman baru. Mereka lebih banyak aktif daripada pasif, dan mereka memiliki kapasitas untuk menghasilkan sesuatu. Mereka memiliki rasa percaya diri dan dapat mengontrol diri Rubinstein dan Firstenberg (dalam Darmiyati Zuchdi 2009:128).

\section{Kepekaan Sosial}

Guru dan dosen sebagai ilmuwan memiliki tanggung jawab sosial karena ia merupakan warga masyarakat dan memiliki fungsi tertentu dalam masyarakat. Fungsi ilmuwan adalah secara terus-menerus melakukan kajian ilmiah dan ikut bertanggung jawab agar produk keilmuan sampai dan dapat dimanfaatkan oleh masyarakat. Tanggung jawab sosial ilmuwan ialah memberikan pandangan atau perspektif yang benar. Dengan kemampuan analisisnya 
atau kemampuannya mengadakan penyelidikan ilmiah, ilmuwan dapat menemukan alternatif pemecahan masalah yang dihadapi oleh masyarakat. Seorang ilmuwan juga memiliki tanggungjawab sosial dan moral untuk dapat memberikan contoh. Ia harus bersikap objektif, terbuka, menerima kritik, menerima pendapat orang lain, kukuh dalam pendirian, dan berani mengakui kesalahan. Untuk dapat berbuat demikian, di samping kemampuan analisis juga diperlukan integritas kepribadian (Suriasumantri, 2005: 237-244).

Mahasiswa dan siswa adalah calon ilmuwan sekalipun masih dalam proses pemeblajaran. Oleh karena itu, setiap siswa dan mahasiswa perlu mempersiapkan diri untuk dapat memikul tanggung jawab sosial seperti yang diutarakan di atas. Mahasiswa dan siswa sebagai status pelajar seharusnya memiliki kepekaan terhadap masalah-masalah yang muncul dalam masyarakat, terutama yang terkait dengan bidang yang menjadi pilihannya. Ia harus mengidentifikasi dan menemukan masalah dengan tepat, kemudian dengan berpikir kritis dan kreatif melakukan analisis atau penelitian guna menemukan alternatif pemecahan masalah tersebut.

Hanya orang-orang yang kreatif yang memiliki kepekaan terhadap lingkungannya dan menyadari hal-hal yang tidak disadari oleh orang lain. Kerap kali kurangnya kesadaran terjadi karena sudah terbiasa berpikir dengan pola-pola tertentu. Orangorang dapat menghasilkan solusi dari suatu masalah dengan baik jika memiliki pandangan bahwa tidak ada sesuatu yang sempurna, kecuali ciptaan Tuhan. Oleh karena itu, setiap hal dapat ditingkatkan atau diperbaiki (Evan, 1980: 40-41).

Kepekaan terhadap masalah-masalah sosial adalah kemampuan untuk menyadari bahwa ada sesuatu masalah yang muncul atau kemampuan untuk memilih satu masalah besar yang kompleks menjadi masalahmasalah yang lebih sederhana serta memisahkan fakta-fakta yang tidak benar, sehingga dapat mengenal masalah sebenarnya. Ada kecenderungan untuk menghasilkan suatu solusi masalah dengan cepat, tanpa memahami masalah yang sebenarnya. Hal ini perlu dihindari, agar diperoleh solusi yang tepat.

\section{Kemitraan Sekolah dan Keluarga Sumber Pendidikan Ketrampilan}

Kerja sama antara sekolah dan keluarga perlu ditingkatkan supaya tidak terjadi kontradiksi atau ketidakselarasan antara nilainilai yang harus dipegang teguh oleh anakanak sekolah dan yang harus mereka ikuti di lingkungan keluarga dan masyarkat. Apabila terjadi konflik nilai, anak-anak mungkin akan merasa bingung sehingga tidak memiliki pegangan nilai yang menjadi acuan dalam berperilaku. Akibatnya, mereka tidak mampu mengontrol dari dalam menghadapi pengaruhpengaruh negative dari lingkungan sekitar mereka.

Pola kemitraan antara sekolah dan keluarga yang bagaimana kiranya efektif, dalam rangka pendidikan nilai dan spiritual bagi masyarakat Indonesia.?. Kemitraan yang diperlukan tentu saja bukan yang bersifat formal berupa penandatanganan surat perjanjian atau yang serupa dengan itu, tetapi yang secara alami dan berkesinambungan dapat menyatukan langkah dalam mendidik putra-putri bangsa Indonesia. Penciptaan suasana yang kondusif bagi pendidikan nilai dan spiritualitas, baik di sekolah maupun di rumah, tampaknya merupakan salah satu bentuk kemitraan yang perlu dikembangkan.

Suasana kehidupan di sekolah dan di rumah mempengaruhi perkembangan kepribadian anak, karena hal itu merupakan wahana penyamaian nilai-nilai yang akan dijadikan acuan oleh anak dalam setiap tindakannya. Apabila anak-anak merasa tenteram ketika berada di sekolah, demikian juga ketika tinggal di rumah, mereka dapat diharapkan memiliki dorongan yang kuat untuk melaksanakan tugas-tugas sekolah dan tugas dirumah dengan sebaik-baiknya. Lebih dari itu mereka akan dengan sukarela menerima dan mengamalkan nilai-nilai positif yang menjadi keyakinan mereka beserta seluruh anggota keluarga. Sebaliknya, apabila 
anak-anak merasa tidak tenang dan gelisah dalam menhadapi pertentangan, tidak dipedulikan, perkembangan intlektual dan emosional mereka akan terhambat.

Suasana kehidupan dalam lingkungan keluarga seharusnya juga dikembangkan selaras dengan suasana sekolah seperti yang telah terungkap . Komonikasi antar anggota keluarga hendaknya bersifat terbuka dan dilandasi dengan rasa kasih sayang yang tulus. Dorongan untuk mencapai yang terbaik sesuai dengan kemampuan masing-masing senantiasa diberikan oleh orang tua, dan kesempatan bekerja sama secara ikhlas perlu dijadikan kebiasaan dalam keluarga bahkan juga dalam masyarakat. Dengan demikian, anak-anak akan menggunakan acuan nilai yang tidak kontradiktif ketika berada di sekolah dan ketika tinggal di rumah, di lingkungan keluarga masing-msing.

Peran guru dan orang tua yang ingin mengembangkan suasana positif di sekolah atau di lingkungan keluarga harus memberikan dorongan kepada anak-anak untuk mengungkapkan gagasan dan perasaan mereka sendiri, membuat keputusan sendiri, dan berpartisifasi dalam menetukan tujuan belajar serta presedur pencapaiannya. Guruguru dan orang tua juga dapat mengatur suasana kelas atau keluarga sedemikian rupa hingga anak-anak mendiskusikan masalah masing-masing secara bersama-sama. Bekerja dan berdiskusi bersama dapat memberikan kesempatan untuk memahami satu sama lain dan memberikan kesempatan untuk berinteraksi.

\section{KESIMPULAN}

Pengembangan keterampilan berpikir kritis dan kreatif serta kepekaan sosial yang telah dibahas di atas hanya mungkin dilakukan apabila siswa memiliki ketrampilan kreatif dan mahasiswa membekali dirinya dengan pengetahuan yang luas, dengan jalan aktif memahami penemuan-penemuan baru dalam bidang ilmu yang diperdalamnya. Salah satu syarat utamanya ialah dengan banyak membaca dan berdiskusi. Namun, perlu disadari bahwa pemecahan masalah sosial secara relatif dapat tuntas hanya mungkin dapat dicapai dengan memanfaatkan berbagai bidang ilmu secara interdisipliner. Hal ini dapat dilakukan antara lain dengan kerja sama mahasiswa dan bidang-bidang ilmu yang berbeda. Misalnya, tiga mahasiswa dan jurusan yang berbeda dapat menyusun proposal penelitian untuk memecahkan masalah sosial yang memang memerlukan pendekatan dari ketiga bidang yang berbeda tersebut.

Pemecahan masalah secara interdisipliner biasanya relatif lebih tuntas daripada yang secara monodisipliner karena cakupan masalah dapat lebih luas dan altematif pemecahannya dari berbagai dimensi. Siswa diberikan tugas-tugas oleh gurunya tiada lain untuk dapat mengembangkan ketrampilan berpikir kritis dan kreatif serta memiliki kepekaan sosial dalam mengikuti proses pembelajaran.

Kemampuan guru mengatasi masalah selain bergantung pada keterampilan berpikir kritis dan kreatif juga pada persepsi seseorang. Guru yang mengajar tidak mungkin dapat mengatasi masalah apabila tidak menyadari adanya masalah-masalah yang muncul dalam kehidupan atau tidak memiliki kepekaan sosial. Guru juga tidak dapat mengatasi masalah apabila takut tidak berhasil. Guru tidak pula berusaha mengatasi masalah apabila merasa tidak berdaya untuk melaksanakannya.

\section{DAFTAR PUSTAKA}

Ahmad Santhut. 2013. Menumbuhkan Sikap Sosial, Moral dan Spiritual Anak dalam Keluarga Muslim. Yogyakarta: Mitra Pusaka.

Alfian,ed. 2009. Persepsi Masyarakat tentang kebudayaan. Jakarta: Gramedia.

Agustian 2002. Rahasia Sukses Membangun Kecerdasan Emosi dan Spiritual. Jakarta: Arga.

Barnadib, Imam. 1999. Beberapa Hal tentang Pendidikan. Yogyakarta: STUDING. 
Dimyati. 2003. Pendidikan Agama pada Masa

Kini dan Perubahan Sosial. Malang:

FAI.UMM.

Suprapto, 1997. Pendekatan-Pendekatan dalam Pengajaran. Jakarta: Raja

Grafindo Persada.

Sumarwati. 2012. Keefektifan Pengajaran Menulis dengan Pendekatan Proses pada Siswa kelas V Sekolah Dasar Negeri dan Suwasta. Tesis tdak dipublikasikan. Institut Keguruandan Ilmu Pendidikan Yogyakarta.

Sariasumantri.2005. Ilmu dalam Persefektif Moral, Sosial, dan Politik. Jakarta: Gramedia.

Zuchdi Darmiyati. 2009. Humanisasi Pendidikan. Jakarat: Bumi Aksara.

2009. Pendidikan Bahasa dan Sastra Indonesia di Kelas Rendah. Jakarta: Primary School Teacher Development Projek. 